
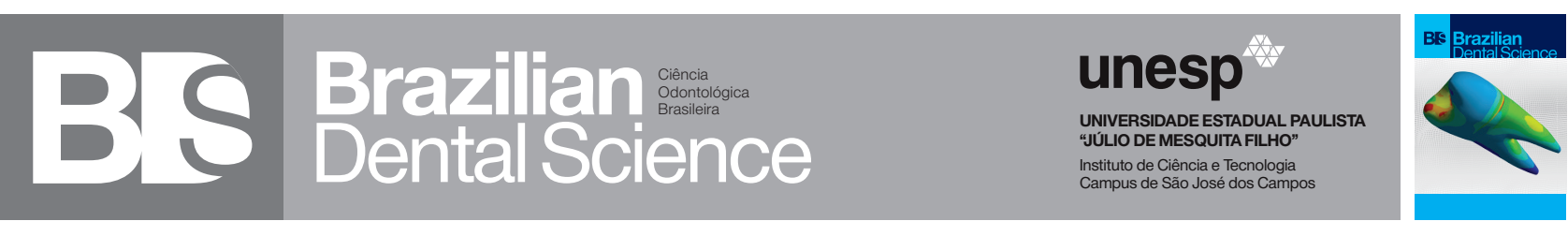

\title{
Comparison of two commercial dentifrices in the reduction of gingivitis and plaque: A pilot study
}

\author{
Comparação de dois dentífricos comerciais na redução da gengivite e da placa bacteriana: um ensaio clínico randomizado \\ controlado \\ Warley David KERBAUY ${ }^{1}$, Erick Shun-Iti MAEDA ${ }^{1}$, Daniel Isaac SENDYK ${ }^{2}$, Cláudio Mendes PANNUTI ${ }^{3}$, Hárina Prates Vilas BÔAS ${ }^{1}$, \\ Emanuel Silva ROVAI ${ }^{3}$ \\ 1 - São Paulo State University (Unesp) - Institute of Science and Technology - São José dos Campos - Department of Diagnosis and Surgery \\ - SP - Brazil. \\ 2 - Department of Oral and Maxillofacial Surgery - College of Dentistry - São Paulo University - SP - Brazil. \\ 3 - Department of Stomatology - Division of Periodontics - College of Dentistry - University of São Paulo - SP - Brazil.
}

\begin{abstract}
Objectives: Chlorhexidine (CHX) and triclosan are the most used chemical agents in dentistry. However, the combination of these products has never been tested. We hypothesize that the addition of CHX to a triclosan dentifrice formulation may offer additional benefits in the reduction of plaque and gingivitis. Thus, the aim of this study was to compare a commercial dentifrice containing $0.05 \%$ chlorhexidine and $0.3 \%$ triclosan, with conventional toothpaste containing $0.3 \%$ triclosan, in the treatment of gingivitis and plaque reduction. Material and Methods: Thirty volunteers were randomly assigned to receive a dentifrice containing $0.05 \% \mathrm{CHX}$ and $0.3 \%$ triclosan (CHX/ triclosan group) or a dentifrice containing basically $0.3 \%$ triclosan (Triclosan group). Subjects received clinical evaluation such as gingival index (GI) and plaque index (PI) at baseline, 30 and 60 days. Results: After 60 days, both treatments led to a significant improvement in GI and PI. There was no significant difference between groups as regards change in GI and PI ( $p>0.05)$. Conclusion: The combination of $0.05 \%$ CHX with $0.3 \%$ triclosan did not offer further benefits to gingival inflammation and plaque control when compared with a dentifrice containing $0.3 \%$ triclosan.
\end{abstract}

\section{KEYWORDS}

Chlorhexidine; CHX dentifrice; Triclosan; Plaque; Gingivitis.

\section{RESUMO}

Objetivos: Clorexidina e triclosan são os agentes químicos mais utilizados em odontologia. No entanto, a combinação desses produtos nunca foi testada. Nós levantamos a hipótese de que a adição de clorexidina a um dentifrício contendo triclosan pode oferecer benefícios adicionais na redução de placa e gengivite. Assim, o objetivo deste estudo foi comparar um dentífrico comercial contendo 0,05\% de clorhexidina e $0,3 \%$ de triclosan, com creme dental convencional contendo $0,3 \%$ de triclosan, no tratamento de gengivite e redução da placa. Material e Métodos: trinta voluntários foram distribuídos aleatoriamente para receber um dentifrício contendo $0,05 \%$ de clorexidina e $0,3 \%$ de triclosan ou um dentifrício contendo basicamente $0,3 \%$ de triclosan. Os indivíduos receberam avaliação clínica de índice gengival (IG) e índice de placa (IP) nos tempos 0 , 30 e 60 dias. Resultados: após 60 dias, ambos os tratamentos levaram a uma melhora significativa no IG e IP. Não houve diferença significativa entre os grupos no que se refere à mudança no IG e IP (p> 0,05). Conclusão: A combinação de 0,05\% de Clorexidina com $0,3 \%$ de triclosan não ofereceu benefícios adicionais para a redução de inflamação gengival e o controle da placa quando comparado com um dentifrício contendo $0,3 \%$ de triclosan.

\section{PALAVRAS-CHAVE}

Clorexidina; Triclosan; Índice de placa; Índice gengival. 


\section{INTRODUCTION}

ingivitis is characterized by a reversible T periodontal inflammation associated with biofilm [1]. Epidemiological studies have shown a high prevalence of this condition, involving over half of the US population [2]. Daily mechanical control by tooth brushing and dental flossing has been shown to be effective in the treatment and prevention of gingivitis. However, achieving an adequate plaque control is difficult for most people [3]. Mechanical control alone reduces dental plaque to 30$50 \%$ only [4]. The result is a high prevalence of dental plaque, dental calculus and gingival bleeding, as shown in epidemiological studies [5]. In this context, the development of new and diverse dentifrice compositions is important in order to optimize the effectiveness of plaque control. Several agents have been studied for their plaque-inhibitory action such as triclosan, sodium fluoride and chlorhexidine[3,4,6,7].

Chlorhexidine (CHX) is an antiseptic with a broad antimicrobial action, including a wide range of Gram-positive and Gram-negative bacteria. Its dental plaque inhibition properties were first investigated by Schroeder [8], and it was confirmed as later by as an effective agent in preventing gingival inflammation and reduction of plaque by Löe and Schiott [9]. Since then, it has played a central role in research, being used in many vehicles such as gels, varnishes, chips, chewing gums, dentifrices and mouthwashes [10-12]. In dental practice, mouthwash is the most used form, though clinical studies has shown that CHX in dentifrices can also offer further benefits to oral health with less tooth discoloration [13]. Moreover, a meta-analysis performed in 2014 showed that CHX dentifrices provide a significant benefit on the treatment of gingivitis and plaque inhibition [14]. Besides that, when used for long periods, CHX has shown to produce local side effects such as tooth staining and taste disturbance $[15,16]$.
Like chlorhexidine, triclosan (2'-hydroxy$2,4,4^{\prime}$-trichlorodiphenyl ether) is also a widespectrum antimicrobial agent [17]. Due to lower incidence of adverse effects, it has been preferably used as an adjunct to mechanical oral hygiene. Triclosan can significantly reduce gingival inflammation and plaque accumulation $[6,18,19]$. Some studies showed antiinflammatory properties, reducing interleukin (IL) $1 \beta$, IL-6, tumor-necrosis factor, and prostaglandins (PG) $[3,20]$. In addition, when used as adjunct to tooth brushing, triclosan also reduce microorganisms related to periodontal disease such as Fusobacteria sp and Veillonella $s p[21,22]$. The literature shows that the use of triclosan as an adjunct to toothbrush provides clinical benefits in comparison with placebo $[6,23,24]$.

The addition of CHX to a triclosan dentifrice formulation may offer additional benefits in the reduction of plaque and gingivitis. However, so far, no study has compared the combination of these two substances with a triclosan dentifrice.

Thus, the aim of this randomized clinical trial was to compare a commercial dentifrice containing chlorhexidine plus triclosan with a conventional toothpaste containing triclosan, in the treatment of gingivitis and plaque reduction.

\section{MATERIALS AND METHODS}

\section{Trial Design and participants}

This was a randomized, double-blind, two-arm parallel-group controlled trial. Participants were selected among those seeking dental treatment at UNESP - São Paulo State University (São José dos Campos, Brazil). The inclusion criteria were: 1 . Patients with at least twenty-four teeth in mouth, 2. 18-35 years old. Exclusion criteria were: 1 . smoking, 2. Presence of braces or other orthodontic appliances, 3 . use of antibiotics 6 months prior to the study and 4. Patients with periodontitis, oral cancers and caries lesions. 
All subjects received intraoral examination and answered a questionnaire comprising questions regarding medical and dental history. The subjects who fulfilled the inclusion criteria were invited to participate in the study. All individuals who agreed to participate were informed about the nature, potential risks and benefits of the study and signed a term of free informed consent. The study was approved by the Ethics Committee of UNESP- Institute of Science and Technology, under the protocol 41294914.7.0000.0077.

\section{Interventions and procedures}

One of the investigators (W.D.K.) was responsible for participant's enrollment and assignment to interventions. The study coordinator (E.S.R) used a computer-generated sequence to randomly assign the subjects to the following two groups: i) CHX/triclosan: Dentifrice produced by Pharmakin, containing chlorhexidine digluconate $0,05 \%$, triclosan 0.30 $\%$, zinc lactate $0.50 \%$ and sodium Fluoride 1450 ppm and ii) Triclosan: (sodium Fluoride 1450 ppm, Triclosan $0,3 \%$ and copolymer (Colgate Total 12®, Colgate Palmolive Co.). Both dentifrices were packaged into identical tubes containing the number to which the participants were assigned.

Initially, all subjects received prophylaxis oral hygiene instructions. The subjects were instructed to use the same toothbrush, dental floss (Kinextra soft, Espanha) and not to use any oral antiseptic solution during the study period. Moreover, the subjects were instructed to use the same amount of the assigned dentifrice during the toothbrushing, which was performed during two minutes, three times a day, during the study period.

\section{Outcomes and blinding}

The primary outcome variable was mean GI reduction (baseline - 60 days). Secondary outcome variables were mean PI and tooth staining after 60 days and PI reduction (baseline
- 60 days).

The following clinical parameters were evaluated at baseline, 30 and 60 days: Gingival index (GI) [25], Plaque index (PI) [26] and Tooth staining (absent/present). Further, the subjects were asked about any adverse effect of the toothpaste during the study.

A single examiner (HVB) performed all clinical examinations. The examiner did not know which dentifrice each participant received. Participants and personnel providing treatment were not aware about the content of their assigned dentifrice.

\section{Statistical analyses}

Mean clinical parameters were computed for each subject and then for each group. Intragroup and intergroup mean differences in GI and PI were evaluated by ANOVA. Student's T-test was used to compare intergroup mean difference as regards age. Fisher's exact test was used to evaluate association between group and tooth staining or gender.

\section{RESULTS}

Subject retention, compliance and adverse effects

Thirty subjects were selected for the study. All participants remained until the end of the follow-up period. Flow chart of the study design is presented in Figure 1. Table 1 depicts clinical and demographic information of the patients. No significant differences were found between the two groups as regards age, gender and baseline clinical parameters $(\mathrm{p}>0.05)$. All subjects reported having followed the instructions during the 60 days of the study.

Two individuals from the CHX/triclosan group presented tooth discoloration. The other subjects did not report any side effects associated with the substances used. 


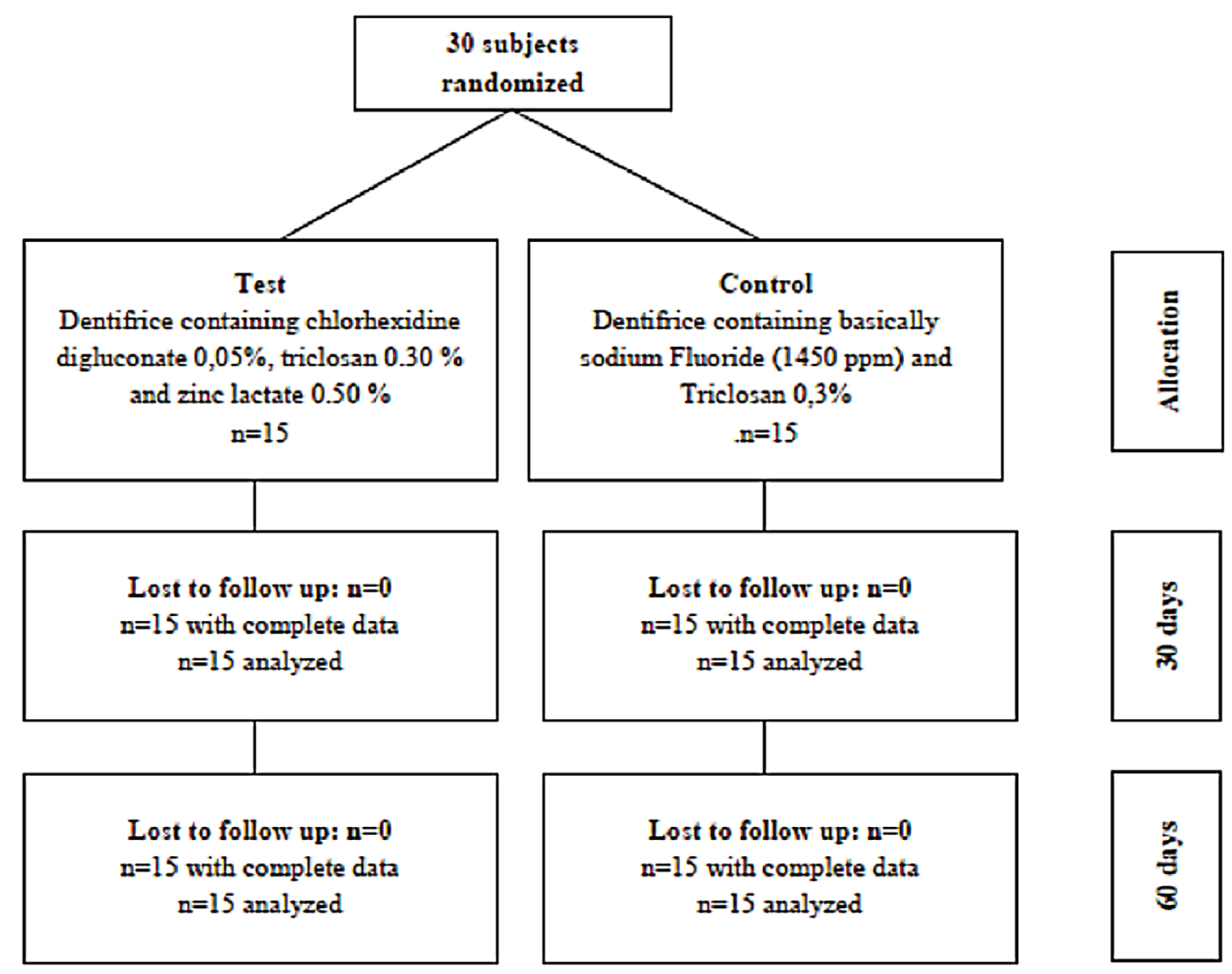

Figure 1 - Flow chart of the study design.

Table 1 - Demographic characteristics and mean \pm SD clinical parameters at baseline, 30 and 60 days

\begin{tabular}{|c|c|c|c|c|}
\hline \multirow[b]{2}{*}{ Variable } & \multicolumn{4}{|c|}{ Treatment groups } \\
\hline & Time point & $\begin{array}{c}\text { CHX/triclosan } \\
n=15\end{array}$ & $\begin{array}{c}\text { Triclosan } \\
n=15\end{array}$ & $\begin{array}{c}\text { One-way ANOVA } \\
\text { p-value }\end{array}$ \\
\hline $\begin{array}{c}\text { Gender } \\
\text { (Male/Female) }\end{array}$ & Baseline & $3 / 12$ & $2 / 13$ & 1.000 \\
\hline Age(Years) & Baseline & $26.27 \pm 1.24$ & $25.07 \pm 0.85$ & 0.4340 \\
\hline \multirow[t]{3}{*}{$\mathrm{Gl}$} & Baseline & $0.37 \pm 0.24$ & $0.49 \pm 0.24$ & $p>0.05$ \\
\hline & 30 days & $0.28 \pm 0.14$ & $0.39 \pm 0.29$ & $p>0.05$ \\
\hline & 60 days & $0.12 \pm 0.08^{*}$ & $0.26 \pm 0.19^{\star}$ & $p>0.05$ \\
\hline \multirow[t]{3}{*}{$\mathrm{Pl}$} & Baseline & $0.76 \pm 0.52$ & $0.76 \pm 0.45$ & $p>0.05$ \\
\hline & 30 days & $0.45 \pm 0.34$ & $0.48 \pm 0.31$ & $p>0.05$ \\
\hline & 60 days & $0.35 \pm 0.34^{*}$ & $0.33 \pm 0.24^{*}$ & $p>0.05$ \\
\hline Tooth staining & Baseline & 0/15 & $0 / 15$ & $p>0.05$ \\
\hline \multirow[t]{2}{*}{ (presence/ absence) } & 30 days & $2 / 13$ & $0 / 15$ & $p>0.05$ \\
\hline & 60 days & $2 / 13$ & $0 / 15$ & $p>0.05$ \\
\hline
\end{tabular}


The significant difference between baseline, 30 and 60 days was assessed using repeated measures ANOVA and Student t-test. Fisher's T-test was used for categorical variables.

The significance of differences between baseline, 30 and 60 days was * Indicate significant differences between time points.

\section{Clinical outcomes}

No statistically significant differences were observed between groups for age, gender, GI, PI and tooth discoloration at baseline, 30 and 60 days ( $p>0.05$ ). After 60 days, both treatments led to a significant improvement in GI and PI.

Table 2 shows the changes in mean GI and PI between baseline and 60 days. There was no difference between groups as regards change in GI and PI.

Table 2 - Mean and SD GI and PI reduction between baseline and 60days.

\begin{tabular}{ccccc} 
Variable & Time point & $\begin{array}{c}\text { CHX/ } \\
\text { triclosan } \\
\mathbf{n = 1 5}\end{array}$ & $\begin{array}{c}\text { Triclosan } \\
\mathbf{n}=15\end{array}$ & $\begin{array}{c}\text { Student } \\
\text { t-test } \\
\mathbf{p} \text {-value }\end{array}$ \\
\hline GI & $0-60$ days & $0.25 \pm 0.23$ & $0.22 \pm 0.27$ & $\mathrm{p}>0.05$ \\
PI & $\mathbf{0 - 6 0 \text { days }}$ & $0.41 \pm 0.10$ & $0.43 \pm 0.08$ & $\mathrm{p}>0.05$
\end{tabular}

GI and PI reduction between groups were analyzed by Student t-test with $5 \%$ of significance.

\section{DISCUSSION}

The results of this randomized clinical trial showed that both dentifrices led to a significant improvement in clinical parameters, although no significant difference between the two groups were found. After 60 days, the clinical improvements observed in both groups were more compatible with studies that investigated the effect of a daily toothbrushing with a triclosan dentifrice $[23,28,29]$ than studies with CHX [30-32]. In this study, the incorporation of
$0.05 \%$ chlorhexidine in a dentifrice containing $0.3 \%$ triclosan (CHX/triclosan group) did not offer further benefits to gingival inflammation and plaque control in comparison with a dentifrice containing $0.3 \%$ triclosan (Triclosan group).

The GI reduction of 0.25 and 0.22 observed in the $\mathrm{CHX} /$ triclosan and Triclosan groups, respectively, are in agreement with other trials which assessed the effects of a dentifrice containing triclosan in these clinical parameters [27-29]. Moreover, in a metaanalysis performed by Hioe \& van der Weijden [23], the authors found an IG reduction of 0.24 and 0.48 in PI, favoring triclosan. The results of this meta-analysis are similar to those of the present study.

CHX is the most effective anti-plaque and anti-gingivitis chemical agent in dentistry [14]. When associated to dentifrices, it has been successfully tested and used in order to enhance mechanical plaque control [14]. However, in this present trial, the association of $0.05 \%$ CHX with $0.3 \%$ triclosan did not result in additional benefits to gingival inflammation and plaque control in comparison with a dentifrice containing $0.3 \%$ triclosan.

An important issue to be considered is the low-dose $0.05 \%$ CHX used in the CHX/triclosan group. The dose-dependent anti-plaque effects of CHX have been shown in vivo studies [33]. Hoffmann [34] assessed the clinical effects of rinsing with a low-dose $0.06 \% \mathrm{CHX}$ in comparison with a commercially available $0.1 \%$ CHX. At the end of the trial, the authors suggested a minimum concentration of $0.1 \%$ CHX if a further decrease in GI is desired.

Furthermore, there are no comparative studies regarding the triclosan when associated with other substances such as CHX, in gingival parameters. Thus, there is no evidence that this association might enhance the anti-gingivitis and anti-plaque effect. Mendes [35] assessed 
the effects of rinsing $0.05 \%$ chlorhexidine, $0.15 \%$ triclosan and $0.18 \%$ zinc pidolate on bad breath. At the end of the study, the authors demonstrated a significant effect on this outcome, however, no major comparisons can be made since the vehicle and outcome assessed were different from the present study.

When CHX is used for long periods, tooth discoloration is the side effect most expected. At 60 days, only two individuals from the CHX/ triclosan group presented tooth staining. This fact might be explained by the low-dose $0.05 \%$ $\mathrm{CHX}$ used in the $\mathrm{CHX} /$ triclosan group. Moreover, there is evidence that the dose-dependent antiplaque effect can be applicable in regards to tooth discoloration $[14,36]$. Therefore, a slight tooth staining was expected in this study.

Since this trial has limitations, the results of the present study might be interpreted with caution. An important issue that must be considered is that the GI and PI of the subjects at baseline were low, which may not represent the majority of the population. In addition, the short-term follow-up period of 60 days and the small sample size $(n=15)$ might have interfered in the results. Thus, the results presented here suggests that the combination of $0.05 \% \mathrm{CHX}$ with $0.3 \%$ triclosan did not offer further benefits to gingivitis reduction and plaque control when compared with a dentifrice containing 0.3\% triclosan. Nevertheless, more studies are needed to corroborate these findings.

\section{CONCLUSION}

The combination of $0.05 \%$ CHX with $0.3 \%$ triclosan did not offer further benefits to gingival inflammation and plaque control when compared with a dentifrice containing $0.3 \%$ triclosan.

\section{REFERENCES}

1. Loe $H$, Theilade $E$, Jensen SB. Experimental gingivitis in man. J Periodontol. 1965 May-Jun;36:177-87.

2. Eke PI, Dye BA, Wei L, Thornton-Evans GO, Genco RJ; CDC Periodontal Disease Surveillance workgroup: James Beck (University of North Carolina, Chapel Hill, USA), Gordon Douglass (Past President, American Academy of Periodontology), Roy Page (University of Washin. Prevalence of periodontitis in adults in the United States: 2009 and 2010. J Dent Res. 2012 0ct;91(10):914-20. Epub 2012 Aug 30.

3. Trombelli L, Farina R. Efficacy of triclosan-based toothpastes in the prevention and treatment of plaque-induced periodontal and periimplant diseases. Minerva Stomatol. 2013 Mar;62(3):71-88.

4. Sälzer S, Rosema N, Hennequin-Hoenderdos NL, Slot DE, Timmer C, Dörfer CE, et al. The effectiveness of a dentifrice without sodium lauryl sulphate on dental plaque and gingivitis - a randomized controlled clinical trial. Int J Dent Hyg. 2017 Aug;15(3):203-210. doi: 10.1111/idh.12201. Epub 2016 Feb 8.

5. Oppermann RV, Haas AN, Rösing CK, Susin C. Epidemiology of periodontal diseases in adults from Latin America. Periodontol 2000. 2015 Feb;67(1):13-33. doi: 10.1111/prd.12061.

6. Riley P, Lamont T. Triclosan/copolymer containing toothpastes for oral health. Cochrane Database Syst Rev. 2013 Dec 5;(12):CD010514. doi: 10.1002/14651858.CD010514.pub2.

7. Ayad F, Mateo LR, Dillon R, Miller JM, Pilch S, Stewart B. Randomized clinical trial of two oral care regimens in reducing and controlling established dental plaque and gingivitis. Am J Dent. 2015 Sep;28 Spec No A:27A-32A.

8. Schroeder HE. Formation and Inhibition of Dental Calculus. J Periodontol. 1969 Nov;40(11):643-6.

9. Löe H, Schiott CR. The effect of mouthrinses and topical application of chlorhexidine on the development of dental plaque and gingivitis in man. J Periodontal Res. 1970;5(2):79-83.

10. Zickert I, Emilson CG, Ekblom K, Krasse B. Prolonged oral reduction of Streptococcus mutans in humans after chlorhexidine disinfection followed by fluoride treatment. Scand J Dent Res. 1987 Aug;95(4):315-9.

11. Francis JR, Addy M, Hunter B. A comparison of three delivery methods of chlorhexidine in handicapped children. II. Parent and house-parent preferences. J Periodontol. 1987 Jul;58(7):456-9.

12. Olympio KP, Bardal PA, de M Bastos JR, Buzalaf MA. Effectiveness of a chlorhexidine dentifrice in orthodontic patients: a randomizedcontrolled trial. J Clin Periodontol. 2006 Jun;33(6):421-6.

13. Supranoto SC, Slot DE, Addy M, Van der Weijden GA. The effect of chlorhexidine dentifrice or gel versus chlorhexidine mouthwash on plaque, gingivitis, bleeding and tooth discoloration: a systematic review. Int J Dent Hyg. 2015 May;13(2):83-92. doi: 10.1111/idh.12078. Epub 2014 Jul 24. 
14. Slot DE, Berchier CE, Addy M, Van der Velden U, Van der Weijden GA. The efficacy of chlorhexidine dentifrice or gel on plaque, clinical parameters of gingival inflammation and tooth discoloration: a systematic review. Int J Dent Hyg. 2014 Feb;12(1):25-35. doi: 10.1111/ idh.12050. Epub 2013 Aug 29.

15. Lang NP, Catalanotto PA, Knopfli RU, Antczak A. Quality specific taste impairment following the application of chlorhexidine gluconate mouthrinse. J Clin Periodontol. 1988 Jan;15(1):43-8.

16. Claydon NC, Addy M, Adams G, Smith SR, Bosma ML, North M, et al. A comparison of two chlorhexidine gel brushing regimens and a conventional toothpaste brushing regimen for the development of tooth staining over a 6-week period. Int J Dent Hyg. 2006 Nov;4(4):183-8.

17. Jones RD, Jampani HB, Newman JL, Lee AS. Triclosan: a review of effectiveness and safety in health care settings. Am J Infect Control. 2000 Apr;28(2):184-96.

18. Teles RP, Teles FR. Antimicrobial agents used in the control of periodontal biofilms: effective adjuncts to mechanical plaque control? Braz Oral Res. 2009;23 Suppl 1:39-48.

19. Vered Y, Zini A, Mann J, DeVizio W, Stewart B, Zhang YP, et al. Comparison of a dentifrice containing $0.243 \%$ sodium fluoride, $0.3 \%$ triclosan, and $2.0 \%$ copolymer in a silica base, and a dentifrice containing $0.243 \%$ sodium fluoride in a silica base: a three-year clinical trial of root caries and dental crowns among adults. J Clin Dent. 2009;20(2):62-5.

20. Barros SP, Wirojchanasak S, Barrow DA, Panagakos FS, Devizio W, Offenbacher S. Triclosan inhibition of acute and chronic inflammatory gene pathways. J Clin Periodontol. 2010 May;37(5):412-8. doi: 10.1111/j.1600-051X.2010.01548.x.

21. Arweiler NB, Henning G, Reich E, Netuschil L. Effect of an aminefluoride-triclosan mouthrinse on plaque regrowth and biofilm vitality. J Clin Periodontol. 2002 Apr;29(4):358-63.

22. Fine DH, Furgang D, Markowitz K, Sreenivasan PK, Klimpel K, De Vizio W. The antimicrobial effect of a triclosan/copolymer dentifrice on oral microorganisms in vivo. J Am Dent Assoc. 2006 Oct;137(10):1406-13.

23. Hioe KP, van der Weijden GA. The effectiveness of self-performed mechanical plaque control with triclosan containing dentifrices. Int J Dent Hyg. 2005 Nov;3(4):192-204.

24. Sälzer S, Slot DE, Dörfer CE, Van der Weijden GA. Comparison of triclosan and stannous fluoride dentifrices on parameters of gingival inflammation and plaque scores: a systematic review and meta-analysis. Int J Dent Hyg. 2015 Feb;13(1):1-17. doi: 10.1111/ idh.12072. Epub 2014 Jun 19.
25. Löe H, Silness J. Periodontal disease in pregnancy. Acta Odontol Scand. 1963 Dec;21:533-51.

26. Quigley G, Hein J. Comparative cleansing efficiency of manual and power brushing. J Am Dent Assoc. 1962 Jul;65:26-9.

27. Deasy MJ, Singh SM, Rustogi KN, Petrone DM, Battista G, Petrone $\mathrm{ME}$, et al. Effect of a dentifrice containing triclosan and a copolymer on plaque formation and gingivitis. Clin Prev Dent. 1991 Nov-Dec;13(6):12-9.

28. Denepitiya JL, Fine D, Singh S, DeVizio W, Volpe AR, Person P. Effect upon plaque formation and gingivitis of a triclosan/copolymer/ fluoride dentifrice: a 6-month clinical study. Am J Dent. 1992 Dec;5(6):307-11.

29. Allen DR, Battista GW, Petrone DM, Petrone ME, Chaknis P, DeVizio W, et al. The clinical efficacy of Colgate Total Plus Whitening Toothpaste containing a special grade of silica and Colgate Total Fresh Stripe Toothpaste in the control of plaque and gingivitis: a six-month clinical study. J Clin Dent. 2002;13(2):59-64.

30. Sanz M, Vallcorba N, Fabregues S, Müller I, Herkströter F. The effect of a dentifrice containing chlorhexidine and zinc on plaque, gingivitis, calculus and tooth staining. J Clin Periodontol. 1994 Jul;21(6):431-7.

31. Olympio KP, Bardal PA, de M Bastos JR, Buzalaf MA. Effectiveness of a chlorhexidine dentifrice in orthodontic patients: a randomizedcontrolled trial. J Clin Periodontol. 2006 Jun;33(6):421-6.

32. Rathe F, Auschill TM, Sculean A, Gaudszuhn Ch, Arweiler NB. The plaque and gingivitis reducing effect of a chlorhexidine and aluminium lactate containing dentifrice (Lacalut aktiv) over a period of 6 months. J Clin Periodontol. 2007 Aug;34(8):646-51. Epub 2007 May 29.

33. Cancro LP, Paulovich DB, Bolton S, Picozzi A. Dose response of chlorhexidine gluconate in a model in vivo plaque system. J Dent Res. 1974;53(3):765

34. Hoffmann T, Bruhn G, Richter S, Netuschil L, Brecx M. Clinical controlled study on plaque and gingivitis reduction under longterm use of low-dose chlorhexidine solutions in a population exhibiting good oral hygiene. Clin Oral Investig. 2001 Jun;5(2):8995.

35. Mendes L, Coimbra J, Pereira AL, Resende M, Pinto MG. Comparative effect of a new mouthrinse containing chlorhexidine, triclosan and zinc on volatile sulphur compounds: a randomized, crossover, double-blind study. Int J Dent Hyg. 2016 Aug;14(3):202-8. doi: 10.1111/idh.12132.

36. Addy M, Sharif N, Moran J. A non-staining chlorhexidine mouthwash? Probably not: a study in vitro. Int J Dent Hyg. 2005 May;3(2):59-63.

\section{Emanuel Silva Rovai (Corresponding address)}

Department of Estomatology, Periodontics

Faculty of Odontology - University of São Paulo

Av Prof. Lineu Prestes 2227 Butantã -São Paulo

ZIP Code: 05508-000 Brazil

Phone: +55 1130917832

Date submitted: 2017 0ct 16

e-mail: emanuel.rovai@hotmail.com 